\title{
Die bestuur van tegnologie en hoëvlakmannekrag: Die identifisering van enkele terreine vir navorsing in Suid-Afrika
}

\author{
N.P. du Preez en R. Uys* \\ Nagraadse Skool vir Bestuurswese, P.U. vir C.H.O., Potchefstroom, 2520 Republiek van Suid-Afrika
}

Received 9 March 1986; accepted 25 October 1986

\begin{abstract}
The managerial function of the modern manager has undergone a shift of focus mainly due to the epidemic rate of technological innovations. Less emphasis is placed on the recurring whilst more time and greater involvement is spent on one-off activities. The modem trend to move from heavy industry to the service sector and high technology has caused a larger and varied need for high level manpower. The manager of today and tomorrow thus has to be equiped with applicable knowledge and skills. However, the following questions need to be answered: what these knowledge and skills are?, in what sense does these differ from the present?, what remains applicable?, the extent of the knowledge on the 'new' requirements?. The aim of this research is therefore to determine the spectrum and facets, the level of research in South Africa and to identify aspects on which research can be undertaken within the fields of management of technology and high level manpower. The total spectrum of management of technology can be devided into three strata namely the macro-, intermediatory- and micro strata, and discussions will centre within this framework. The micro strata is a compilation of the technology process and its elements and other factors which might have an influence thereon or be dependent thereupon. The various elements of the technology process are discussed separately while each element is defined precisely. The present state of knowledge on this specific subject is outlined and areas for future research are identified. Identical aspects are discussed under the headings of the various other elements that function within the framework of management of technology but external to the technology process. The prime objective of the preliminary investigation on management of high level manpower was to identify the elements of management that will possibly change or expand during the management of high level manpower. Thereby a structure could be developed whereby information and techniques could be gathered and developed for the management of these activities.
\end{abstract}

Die bestuurstak van die moderne bestuurder het veral weens die epidemiese afmetings wat tegnologiese innovasie aanneem, 'n klemverskuiwing ondergaan. Daar word nou veel minder klem op herhalende aktiwiteite gele en meer tyd en betrokkenheid word aan eenmalige aktiwiteite afgestaan. Die hedendaagse verskuiwing vanaf die swaar nywerheid na die dienstesektor en hoi tegnologie het ook 'n verhoogde en gewysigde behoefte aan hoèvlakmannekrag meegebring. Die bestuurder van vandag en môre moet gevolglik vir die bestuur van hierdie tegnologie en hoëvlakmannekrag met bepaalde kennis en vaardighede toegerus word. Die vraag ontstaan wat hierdie kennis en vaardighede is, tot watter mate dit van die huidige verskil, wat bly steods toepaslik, en hoeveel kennis daar oor die 'nuwe' vereistes bestaan. Die doelwitte van hierdie navorsing is onder andere om die spektrum van dimensies en fasette, die stand van navorsing in Suid-Afrika en bepaalde terreine waarop navorsing ten opsigte van beide die bestuur van tegnologie en hö̌vlakmannekrag gedoen kan word, te identifiseer. Die totale spektrum van die bestuur van tegnologie word in drie strata, naamlik die makro-, intermediêre- en mikrostrata, verdeel en ook as sulks bespreek. Die mikrostrata is ' $n$ samestelling van die tegnologieproses en sy elemente asook van ander faktore wat ' $n$ invloed daarop mag hê of daarvan afhanklik is. Die samestellende elemente van die tegnologieproses word eerstens afsonderlik bespreek en dek aspekte soos: die huidige stand van kennis oor 'n bepaalde onderwerp en dan word daar besondere klem op toekomstige terreine vir navorsing gele. Vervolgens word dieselfde aspekte ten opsigte van die elemente van die bestuur van tegnologie wat buite-om die tegnologieproses funksioneer, bespreek. Daar is gepoog om met die loodstudie oor die bestuur van hö̌vlakmannekrag die elemente van die bestuur van mannekrag te identifiseer wat tydens die bestuur van hoëvlakmannekrag wysig of verdiep. Sodoende sou 'n raamwerk daargestel kon word waardeur toepaslike inligting en tegnieke deur navorsing versamel en ontwikkel kan word vir die bestuur van hierdie aktiwiteite.

* Aan wie korrespondensie gerig moet word

\section{Inleiding en Probleemstelling}

Die vermoẻ om die spesifiseerbare te bestuur, is feitlik vervolmaak. Die bestuurstaak het egter gedurende die tweede helfte van hierdie eeu meer kompleks geraak. Met tegnologiese innovasie wat 'epidemiese' afmetings aanneem, word die bestuurstaak nou deur onsekerheid, snelle verandering, risiko en innovasie gekenmerk. Die feit dat die mens, waardeur ondernemings bestuur en bedryf word, van nature stadiger aanpas as wat die tegnologie ontwikkel, stel bestuur voor nuwe uitdagings in die 20 ste eeu. Groot hoeveelhede tegniese en intellektuele bronne word vir die hantering en oplossing van hierdie bepaalde probleme vereis. Die vraag ontstaan onwillekeurig of die bestaande bestuurskennis voldoende en/of toepaslik is om hierdie groot hoeveelhede tegnologiese ontwikkelings en betrokke hövlakmannekrag te bestuur.
Uit bogenoemde vraag kristalliseer twee belangrike aspekte, naamlik: (i) Die bestuur van tegnologie en(ii) Die bestuur van hoëvlakmannekrag ${ }^{1}$.

Utterback (1971 : 76) het daarop gewys dat tegnologiese innovasie op internasionale handel, bedryfstrukture, die samestelling en ontwikkeling van nuwe ondernemings en bedrywe, en die groei en oorlewing van bestaande ondernemings en bedrywe 'n invloed het, en dat bestuur van tegnologie meer as 'n sleutel tot kompeterende voordeel is. Volgens Utterback (1971 : 76), Feder (1981 : 1Oe) en Drucker (1985 : xii) is dit 'n komplekse probleem en behels dit meer as die ooglopende administrasie van navorsings- en ontwikkelingsprogramme. Dit is eerder 'n vereiste vir ekonomiese oorlewing.

Terwyl die behoefte aan kennis en begrip aangaande 
die ontwikkeling van tegnologie duidelik is, is die bestaande kern van sistematiese kennis op hierdie gebied relatief klein. 'n Besliste probleem binne hierdie navorsingsveld is die behoefte aan die ontwikkeling en sistematisering van definisies, maatstawwe en ' $n$ model wat die proses van innovasie binne die onderneming en die onderneming se omgewing, asook die kompleksiteit van die proses en die betekenisvolle veranderlikes en verhoudings wat dit beinvloed, in ag neem.

Hierdie gebrek aan gesistematiseerde kennis aangaande tegnologie en die bestuur van tegnologie, gekoppel aan die omvangryke invloed daarvan op interen intra-organisatoriese vlak, veral ten opsigte van die toepassing in die Suid-Afrikaanse milieu, vorm die kern van die een sy van die vraagstuk.

Die gelydelike ommeswaai vanaf die sekondêre sektor na die tersiêre sektor, byvoorbeeld finansies, versekering en besigheidsdienste, en gevorderde tegnologie het egter ook 'n verhoogde en gewysigde behoefte aan hoëvlakmannekrag meegebring. Geneem teen konstante 1980-pryse het die tersiere sektor se bydrae tot die BBP vanaf $31,4 \%$ (1980) tot $34 \%$ (1985) toegeneem. Hierteenoor het die sekondère sektor se bydrae tot die BBP vanaf $21,7 \%$ (1980) tot $19,4 \%$ (1985) afgeneem (Statistiese/ ekonomiese oorsig, 1986/87: 7). Hierdie verhoogde vraag, gekoppel aan die relatiewe onelastisiteit van aanbod en verhoogde taksering, het tot toenemende fokus op die aanwending en bestuur van hierdie mannekrag gelei. Hierdie fokus is belangrik aangesien die proses deur onsekerheid gekenmerk word.

In die geval van nie-herhalende prosesse kan die proses nie gespesifiseer word nie, die gevolge kan nie bepaal word nie en 'n taakomskrywing kan nie akkuraat opgestel word nie. Die poste wat binne hierdie kriteria ressorteer is gevolglik kompleks om te bestuur.

Dit lyk dus asof 'n 'nuwe' bestuursteorie en -praktyk ontwikkel moet word, wat van toepassing is op die gebiede waar tegniese en intellektuele bronne die dominante rol vervul. Bestuur sal in hierdie geval primèr betrokke wees by die werwing en behoud van hoëvlakmannekrag, asook die motivering, ontwikkeling en uitbou daarvan. ' $n$ Verdere funksie van bestuur is die ontwikkeling van ' $n$ inligtingsomgewing wat deur hoëvlakmannekrag benut kan word.

\section{Doel van die studie}

Die studie is onderneem om vanuit 'n teoretiese begronding, aangevul deur inligting wat uit 'n relatief omvattende empiriese studie verkry is, terreine vir navorsing ten opsigte van die bestuur van tegnologie en hoëvlakmannekrag te identifiseer, ontleed en sistematiseer. Die klem in hierdie studie val primèr op die identifisering van terreine vir verdere navorsing ten opsigte van die Suid-Afrikaanse situasie.

\section{Navorsingsmetodiek}

Ten einde die navorsingsdoelwitte te bereik is

- ongestruktureerde onderhoude met 'n verteenwoordigende, heterogene groep van eksponente van die vakgebiede gevoer; en

- 'n literatuurstudie is oor die onderskeie onderwerpe gedoen.

Die ongestruktureerde inligting wat tydens voorgenoemde onderhoude versamel is, is deur middel van ontledingsmatryse gestruktureer .

Die onderskeie fasette, soos deur middel van die ontledingsmatryse geidentifiseer, is vervolgens in homogene navorsingsvelde gegroepeer om 'n aanvanklike bydrae tot die sistematisering van inligting van die terreine te lewer. Modelle is ontwikkel waarin die interafhanklikheid van die elemente van die bestuur van tegnologie en hoëvlakmannekrag aangedui word. Hierdie modelle vorm die kern van die artikel en dien as riglyn vir beide die kort oorsig oor elk van die elemente en die identifisering van navorsingsvelde.

\section{Bestuur van tegnologle}

\section{Oriëntering}

Tegnologie het 'n belangrike element van ons lewens geword, met 'n impak wat voortdurend toeneem. Daar word baie sosiale en politieke kommer uitgespreek oor die wyses waarop tegnologie ons lewenswyse en werk beinvloed en of dit wenslik en beheerbaar is.

In die literatuur is daar verskeie definisies van tegnologie en innovasie, byvoorbeeld Van Wyk (1985: 4), Miner (1985 : 598) en Utterback (1974 : 658). Kortliks kan dit gestel word dat tegnologie as hulpmiddel tot die verbetering van transformasieprosesse dien. Dit gee meer alternatiewe met besluitneming en probleemoplossing en verskaf gereedskap om take mee uit te voer.

Die modelle waarin die interafhanklikheid van die elemente van die bestuur van tegnologie aangedui word, word in Figure 1 - 3 weergegee.

Die omgewing waarmee ondernemings in wisselwerking verkeer, bestaan uit drie vlakke, naamlik 'n makrovlak (kulturele, politieke en ekonomiese stelsels), 'n intermedière vlak bestaande uit die netwerke (bemarking, logistiek, vakunies en tegnologie) waardeur die ondememing met die makrovlak verbind is, en 'n mikrovlak bestaande uit die stelsels binne die grense van die

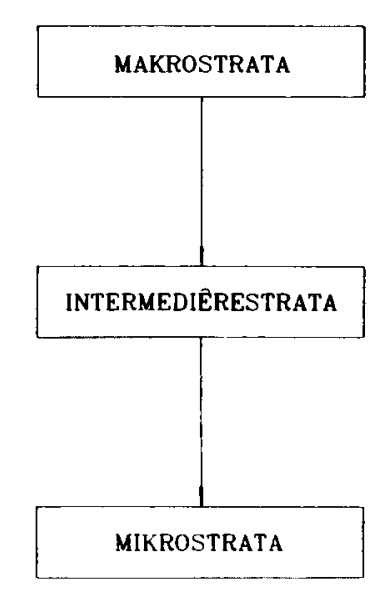

Figuur 1 Die strata van die bestuur van tegnologie 
onderneming. Soortgelyk kan die bestuur van tegnologie in drie strata verdeel word. Elk van hierdie strata word vervolgens bespreek.

\section{Makrostrata}

\section{Nasionale strategie vir die bestuur van tegnologie}

Een van die belangrikste uitdagings vir industriële ekonomiee is die vermoè om nuwe industrieè uit tradisionele industriee te ontwikkel. Die geskiedenis het bewys dat die proses van tegnologiese innovasie en aanpassing die sleutel tot kontinue ekonomiese groei is. Dit is 'n komplekse proses wat 'n kombinasie van produksiefaktore soos risikokapitaal, hoëvlakmannekrag en entrepreneurs insluit.

Die ontwikkeling van hierdie nuwe industrieë uit die tradisionele industrieë is 'n komplekse proses. Die belangrikste faktore wat tot die suksesvolle toepassing van gevordende tegnologie lei is:

- die beskikbaarheid van beleggings- of risikokapitaal;

- die beskikbaarheid van hoevlakmannekrag; en

- die teenwoordigheid van entrepreneurs wat die vereiste vir risiko-investering verstaan, en wat op 'n effektiewe en doeltreffende wyse die kapitaal en geskoolde mannekrag kan integreer om innovasies en skeppende denke in winsgewende produksie te transformeer.

'n Noukeurige ondersoek van die kombinasie van hierdie faktore het daarop gedui dat 'n vierde faktor ' $n$ rol speel in die ontwikkeling van gevorderde tegnologiese ondernemings. Die teenwoordigheid van uitmuntende akademiese instellings speel ' $n$ belangrike rol in hierdie proses, aldus Howell (1985: 19).

Tydens die projek het die respondente dit beklemtoon dat een van die belangrikste probleme in Suid-Afrika die dualistiese ekonomie is. Verder word die probleem vererger deur die gebrek aan hoëvlakmannekrag en geskoolde arbeid.

Die vraag kan gevra word of Suid-Afrika nie ryp is vir 'n nasionale strategie vir tegnologie nie. Wat nou dringend noodsaaklik geword het, is navorsing ten opsigte van die behoefte aan ontwikkeling en implementering van 'n nasionale strategie vir tegnologie. Dit is van wesenlike belang vir die herstel in die SuidAfrikaanse ekonomie, voortgesette groei in die ekonomie en die skepping van werkgeleenthede.

\section{Intermedière strata}

Onder intermedière strata van tegnologiebestuur word die intra-industriële bestuur van tegnologie verstaan. Dit behels substelsels soos intermedière netwerke, -databasisse, -tegnologie-industrieè en tegnologiese navorsing deur nasionale navorsingsinstellings.

In 'n onlangse artikel wys Cash \& Konsynski (1985: 134) daarop dat inligtingstelsels die grense van mededinging tussen ondernemings kan verander. Kaufman (1966: 141) het beklemtoon dat bestuurders die moontlikheid van intrakorporatiewe stelsels moet ondersoek. Vandag is die mees dramatiese en potensieelkragtige gebruik van inligtingstelseltegnologie die benutting van intrakorporatiewe netwerke. Hierdie net- werke het implikasies vir sosiale- en regeringsbeleidformulering en lewer 'n bydrae tot die verhoging van produktiwiteit, buigsaamheid en kompeterende voordele vir ondernemings. Intermediêre bestuur van tegnologie kan ook die struktuur van ' $n$ industrie beïnvloed.

\section{Mikrostrata en die tegnologieproses}

Die belangrikste elemente van die mikrostrata van die bestuur van tegnologie word in Figuur 2 vervat. Die tegnologieproses vorm die kern van die mikrostrata en is in Figuur 3 uiteengesit. Figuur 2 weerspieèl die wederkerige interafhanklikheid tussen die tegnologieproses en ander elemente van die substelsel enersyds en die uitkringende invloed van tegnologie andersyds. Dit verteenwoordig in effek die spektrum van die bestuur van tegnologie intern tot die onderneming.

In die konteks van voorgenoemde word die tegnologieproses vervolgens aan die hand van Figuur 3 bespreek.

\section{Vooruitskatting van tegnologie}

Tegnologie is reeds 'n geruime tyd die dominante krag agter verandering. Dit is egter eers onlangs dat bestuur die noodsaaklikheid van tegnologiese vooruitskattings en die invloed daarvan op hul aktiwiteite besef het.

Volgens Quinn (1967 : 89) is dit belangrik dat die doelwit met tegnologievooruitskatting voortdurend in gedagte gehou word. Die vooruitskatting van tegnologie kan bestuur help om geleenthede en bedreigings in die omgewing van die onderneming te identifiseer ten einde meer effektief op te tree en sodoende die onderneming se toekomstige posisie te verbeter. Daar bestaan bepaalde tegnieke om sodanige vooruitskattings te doen. Daar moet in gedagte gehou word dat daar beperkings

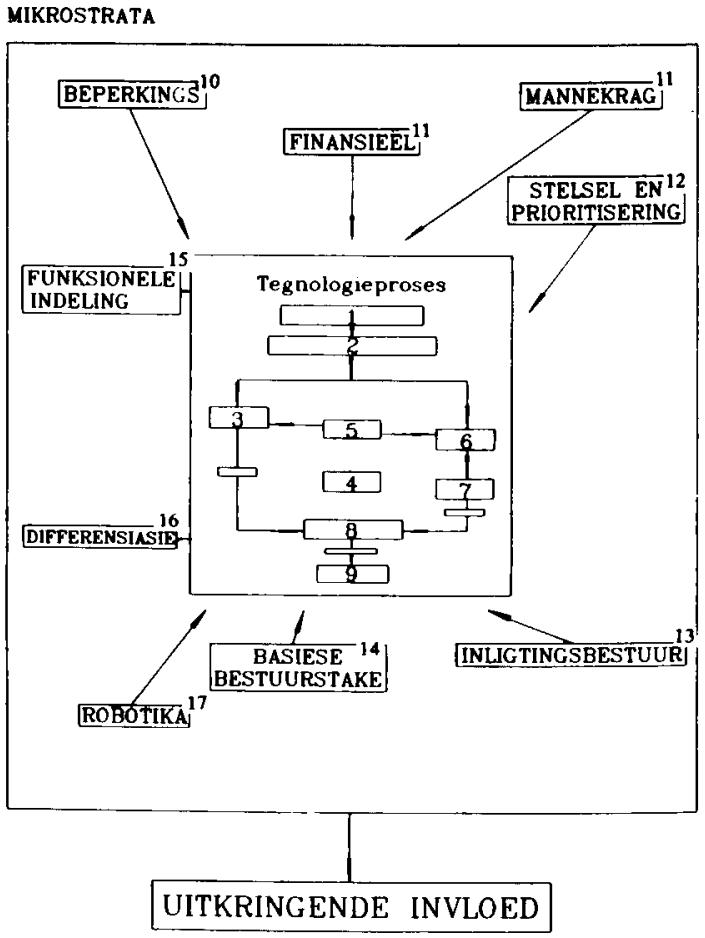

Flguur 2 Die mikrostrata van die bestuur van tegnologie 


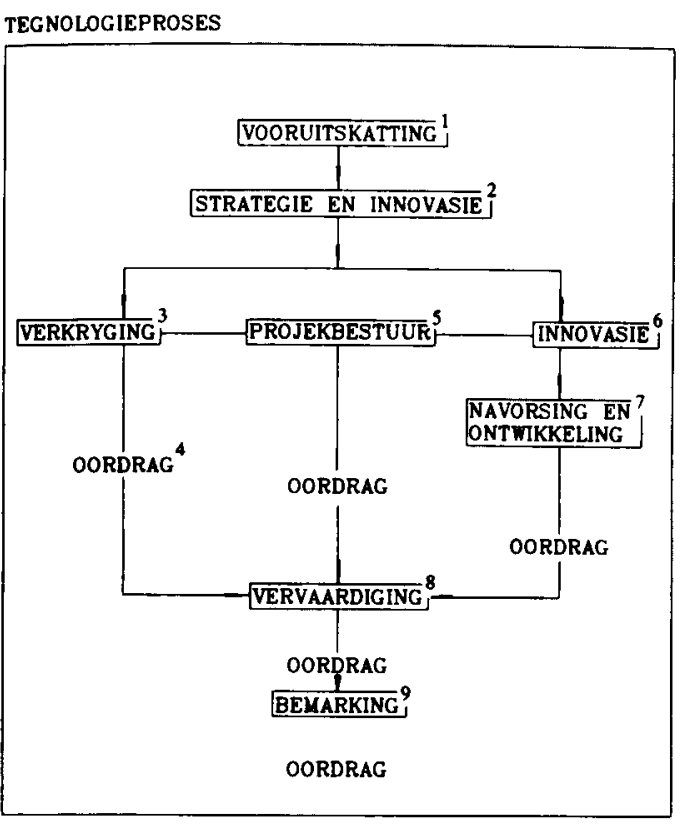

Flguur 3 Die tegnologieproses

op vooruitskattings is, onder andere weens onvoorspelbare interaksies, onvoorsiene vereistes, belangrike ontdekkings en onvoldoende inligting.

\section{Strategie en innovasie}

Tegnologie is 'n onontbeerlike mag in die kompeterende omgewing van die moderne onderneming en die rol van topbestuur in tegnologiese verandering en ontwikkeling in 'n onderneming is van kardinale belang. Van wesenlike belang is die feit dat topbestuur tydens die ontwikkelingsfase van nuwe tegnologieë ' $n$ veel groter invloed op die prestasie van die onderneming kan lewer as tydens enige ander fase. Volgens Maidique \& Patch (1978 : 273) word 'n eksplisiete strategie en beleid vir tegnologie selde in die korporatiewe strategie van 'n onderneming gevind.

Die beleid vir tegnologie sluit in die keuse tussen alternatiewe nuwe tegnologiee, die kriteria wat bepaal hoe hierdie tegnologiee by nuwe produkte en prosesse ingesluit word, en die anwending van hulpbronne wat die suksesvolle implementering van tegnologiese verandering sal verseker. Dit bestaan dus uit 'n portefeulje van keuses en planne wat die onderneming in staat stel om effektief te reageer op die tegnologiese bedreigings en geleenthede in die omgewing. In die formulering van die tegnologiebeleid van die onderneming is daar ses basiese keuses wat die onderneming moet maak. Hierdie keuses behels die keuse en spesialisasie van nuwe tegnologieë, vlakke van vaardigheid, bronne van tegnologie, die investering in navorsing en ontwikkeling, kompeterende tydsberekening en die strukturering van die onderneming vir tegnologiese ontwikkeling.

Verkryging van eksterne tegnologie

'n Opvallende kenmerk van die huidige ekonomiese scenario is die omvangryke vloei van tegnologie tussen geindustrialiseerde lande, asook tussen geìndustrialiseerde en ontwikkelende lande. Dit is belangrik om die beste wyse waarop tegnologie en tegnieke verkry, geabsorbeer en by die plaaslike omstandighede aangepas kan word, te bepaal. Die verkryging van tegnologie beteken in hierdie geval die verkryging van kennis, ondervinding en vaardighede noodsaaklik vir die vestiging van 'n bedryf en die vervaardiging van produkte (United Nations, $1973: 1$ ).

Die kruisvloei van tegnologie tussen bedrywe en ondernemings in verskillende lande is normaalweg op ' $n$ tegnologielisensie, wat die reg verleen om gepatenteerde tegnologie vir die doel van vervaardiging aan te wend, gebaseer. Die land wat die tegnologie ontvang (verkry), beskik normaalweg oor 'n tegnologiegrondslag. Die doel met die verkryging van tegnologie is dus die verkleining of sluiting van spesifieke tegnologiegapings.

\section{Die oordrag van tegnologie}

Volgens De Jesus (1983 : 6) kan die oordrag van tegnologie gedefinieer word as die doelbewuste en doelgerigte oordrag van tegnologiese kennis van een groep na 'n ander.

De Jesus ( 1983 : 66) gaan dan verder en stel dat die bestuur van die oordrag van tegnologie die volgende behels: 'Management of technology transfer can be seen as the conscious, deliberate, intelligent manipulation of resources and conditions so as to achieve and control the quality and quantity of technology to be transferred.'

Hierdie doelbewuste, doelgerigte oordrag van tegnologie vanaf 'n versender na 'n ontvanger vind meervoudig binne die totale spektrum van tegnologiebestuur plaas en word in Figuur 4 aangedui.

Die proses van die oordrag van tegnologie is 'n besigheids- en bestuursproses en nie 'n tegnologiese proses nie. Die oordrag vind tussen die navorsing- en die ge(ver)bruikerstelsel plaas en gaan gepaard met 'n besigheidstransaksie waarby probleme soos installering, inbedryfstelling, bedryf en impak betrokke is.

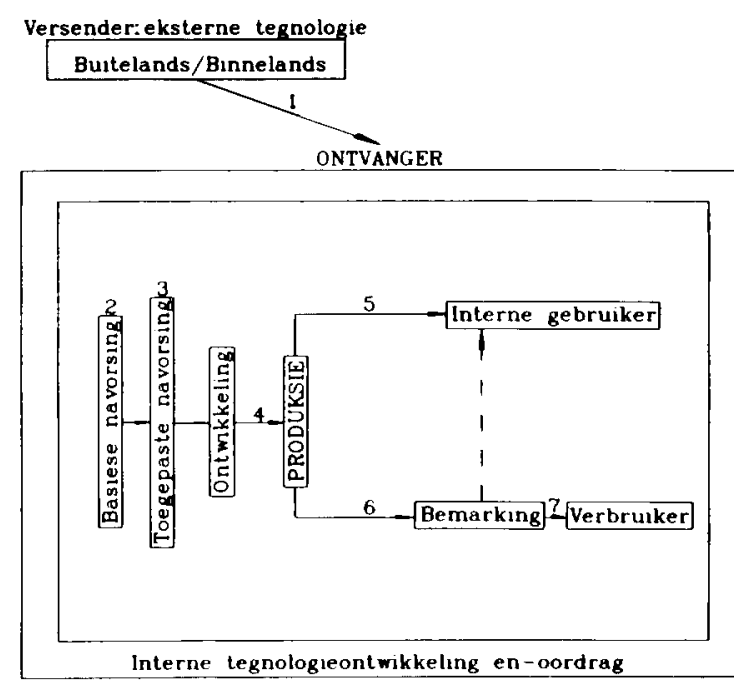

(Die punte warop tegnologie oorgedra word vanaf 'n versender na $n$ ontvanger is opeenvolgend genommer)

Figuur 4 Die oordrag van tegnologie 


\section{Tegnologiese innovasie}

Die proses van oorsprong, ontwikkeling en bekendmaking van tegnologiese ontwikkelings lê aan die kem van die industriële onderneming. In die geval van 'n groeiende industrie kan dit tot 'n groot kompeterende voorsprong lei. By 'n volwasse industrie kan dit tot diversifikasie en heraanwending van produkte aanleiding gee. Omgekeerd kan dit tot die oorname van tradisionele markte en die vervanging van tradisionele produkte by ander ondernemings lei. Innovasie is gevolglik vir bestuur met betrekking tot beide die groei en oorlewing van ondernemings, produkte en markte belangrik.
Vir 'n onderneming om innovasie tot groot voordeel aan te wend is dit belangrik om die innovasieproses en die betrokke bestuursaktiwiteite te integreer. Die innovasieproses is reeds deur Utterback (1971: 125) geidentifiseer en gesistematiseer en word in Figuur 5 weergegee.

Bo en behalwe die bestuur van die innovasieproses, is daar 'n belangrike ongedefinieerde bestuurstaak in die hantering van weerstand teen innovasie, die vermindering en voorkoming van negatiewe gevolge weens weerstand teen innovasie en in die neem van bepaalde stappe om innovasie te bevorder.

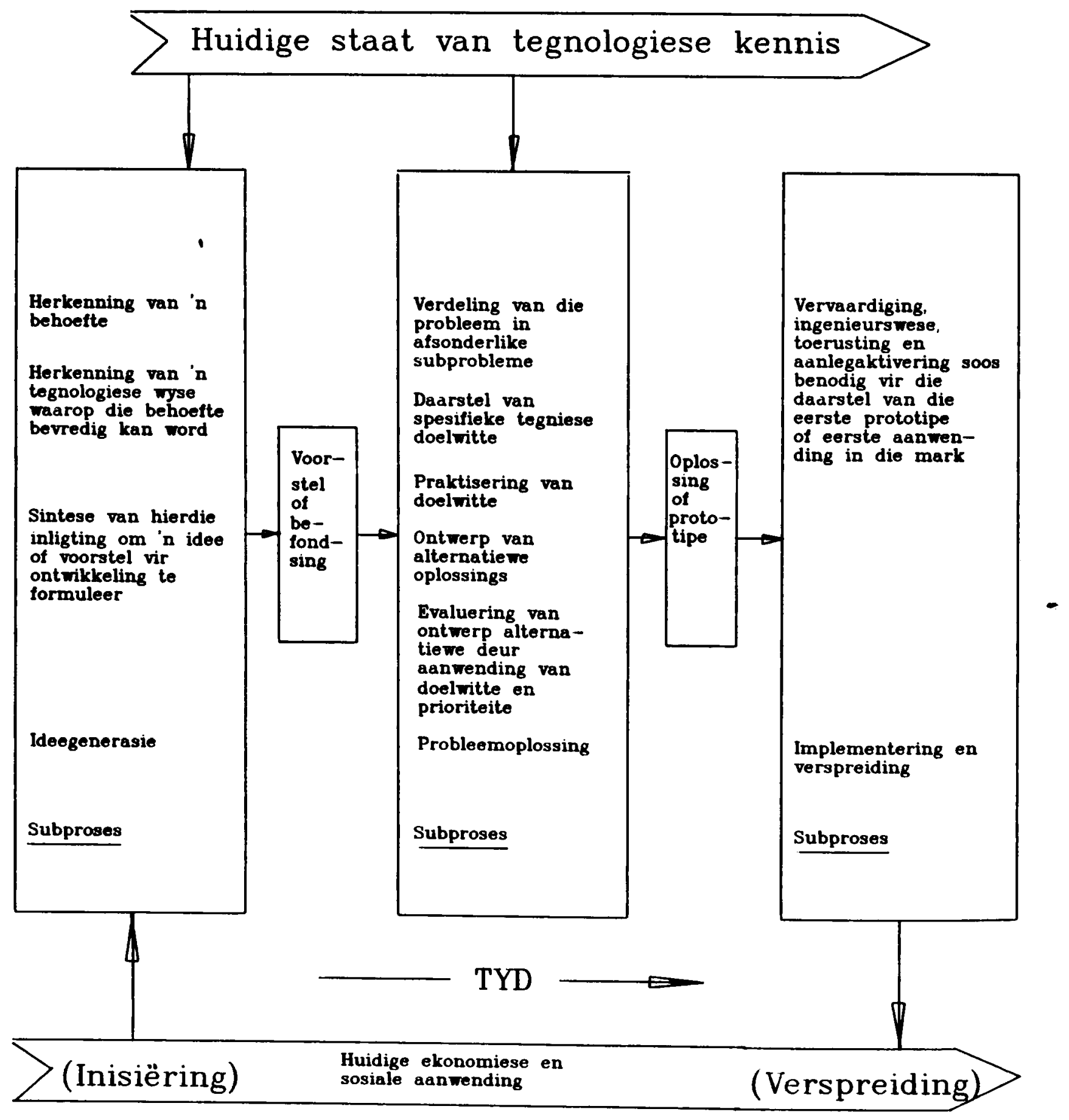

(Utterback, 1973 125) 


\section{Vervaardiging}

Wêreldwyd word vervaardigingsondernemings deur toenemende mededinging in die gesig gestaar. Dit is 'n feit dat inligting vervaardigingsprodukte as die belangrikste komponent in die bruto binnelandse produk van die belangrikste nywerheidslande vervang. In SuidAfrika kan die tendens van ' $n$ verskuiwing in die samestelling van die BBP waargeneem word (verwys Statistiese/ekonomiese oorsig, 1986/87). Daar is ook toenemende bewys dat vervaardiging as 'n kragtige kompeterende voordeel deur mededingers benut word. Wat die uitdaging so moeilik maak, is die feit dat die geheime wapen van mededingers nie gebaseer is op 'n beter produkontwerp, bemarkingsinnovasie of finansiële hulpbronne nie, maar dit is die ontwikkeling van superieure vervaardigingskapasiteite wat ' $n$ belangrike rol in mededinging speel.

Die rekenaar word vir die koördinering en beheer van die totale produksieproses, vanaf ontwerp en spesifikasies, deur die verkryging en kwaliteitsbeheer van roumateriaal en onderdele, en tot finale verskeping en distribusie, benut. Arbose (1985: 12) verwag dat volgehoue outomatisering en die toepassing van nuwe kennis op alle vlakke van die fabriekswese binne die volgende vyf tot tien jaar tot rekenaargeintegreerde vervaardiging (CIM), die sogenaamde fabriek van die toekoms, sal lei. Wheelwright \& Hayes $(1985: 100)$ beklemtoon ook die strategiese rol van tegnologie in vervaardiging.

Suid-Afrika se produktiwiteitsyfer is van die laagste in die wèreld, en vergelyk baie swak met van die belangrikste handelsvennote van die Republiek. Die toepassing van nuwe tegnologiee in die Suid-Afrikaanse vervaardigingsindustriee is kritiek belangrik vir verhoging in produktiwiteit, maar ook om aan SuidAfrikaanse ondernemings 'n kompeterende voordeel te verskaf.

Baperkings op tegnologie(se ontwikkeling)

Dit is 'n paradoks dat 'n groot knelpunt van die SuidAfrikaanse ekonomie sy rykdom aan (minerale) bronne is. Die sterkte van die industrie het veroorsaak dat die behoefte aan 'n gesonde sekondere sektor afgeskeep is. Volgens Kates (1975: 8) is 'n ekonomiese struktuur daarsonder ongebalanseerd en die ekonomiese opsies onbuigbaar. Nuwe tegnologie is een van die noodsaaklike komponente van nywerheidsinnovasie, en dit is reeds geïdentifiseer as 'n behoefte binne die SuidAfrikaanse ekonomie.

Ten spyte daarvan dat 'n sterk binnelandse tegnologiebedryf 'n groot aanwins vir die land sal wees, kom dit steeds nie tot sy volle reg nie. Tydens die loodsstudie is 'n aantal beperkende faktore tot die ontwikkeling van ' $n$ Suid-Afrikaanse tegnologiebedryf geidentifiseer. Hier die faktore word in Figuur 6 aangedui. Die omvang en invloed van hierdie faktore moet egter deur navorsing bepaal word.

Die bestuur van inligtingstegnologie

Stonier (1983: 9-214) waarsku dat die stygende werk loosheidsyfer in die Westerse wêreld op strukturele ver- anderings dui. Volgens hom is daar ' $n$ nuwe verskuiwing vanaf die industriële ekonomie na 'n ekonomie waar rykdom deur inligting gegenereer kan word.

Volgens Dizard (1982: xiii) leef ons aan die begin van die inligtingseeu en behoort daar binne die volgende vier dekades ' $n$ universele elektroniese inligtingsnetwerk, wat in staat sal wees om enige persoon te bereik, te bestaan. Die probleme wat nou aangespreek behoort te word, is op die terrein van die ekonomiese en sosiopolitiese omgewings. Volgens hom is die koördinasie tussen die tegnologie en laasgenoemde twee fasette baie dringend om geleenthede te identifiseer vir 'n nuwe inligtingverrykte beskawing. Tegnologiese ontwikkelings op die terrein van tegnologiebestuur is steeds besig om teen 'n geweldige tempo te vorder. Dit bly dus 'n belangrike terrein vir navorsing.

\section{Differensiasie}

Die respondente se terugvoer dat die bestuur van tegnologie 'anders' is word hoofsaaklik op drie eienskappe van tegnologie gebaseer, naamlik: onstabiliteit, kompleksiteit en risiko.

Die voorkoms van hierdie eienskappe binne bepaalde vakgebiede kan diagrammaties śoos in Figuur 7 voorgestel word.

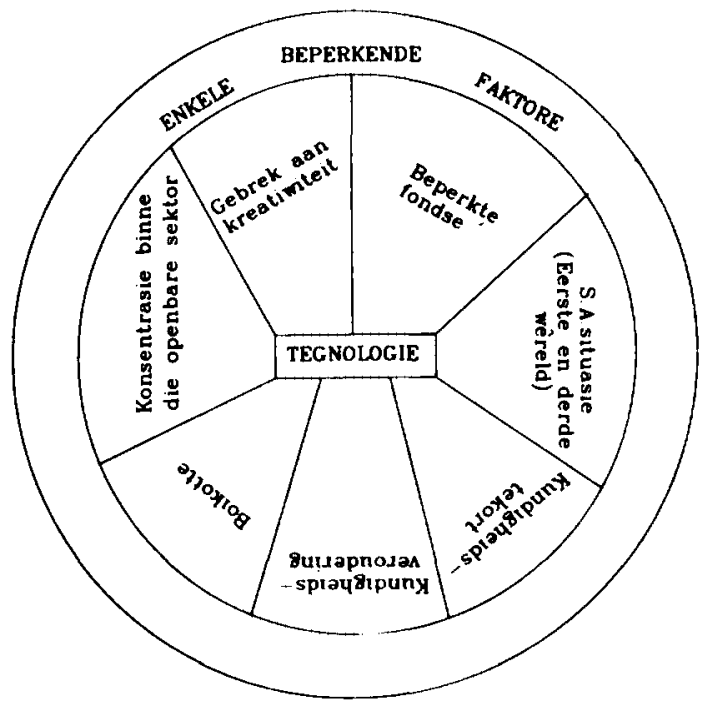

Figuur 6 Enkele faktore wat tegnologie(se ontwikkeling) beperk

KOMPLEKSITEIT

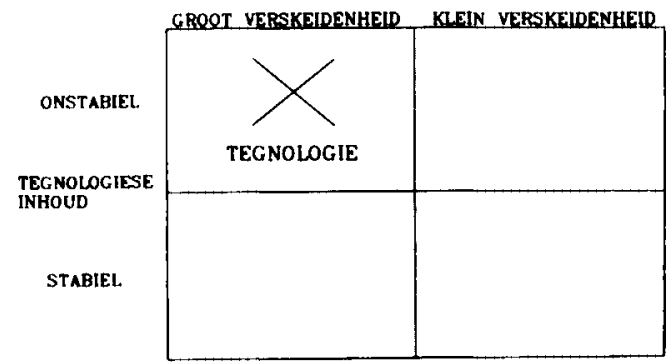

Figuur 7 Differensiasie binne bepaalde vakgeblede 
Weens die ho'e mate van kompleksiteit en onstabiliteit van die inhoud van tegnologie is daar 'n hoe mate van risiko aan verbonde. As dit dan gekoppel word aan die feit dat die tydsduur van die ontwikkeling van tegnologie veel langer is as die uiteindelike lewe van die tegnologie, word die bestuurstaak verder gekompliseer.

Die presiese mate waartoe dit gekompliseer word, die wyse waarop die bestuurstaak aangepas moet word en die aspekte wat geraak word is egter nie bekend nie.

\section{Uitkringende invloed van tegnologie}

Dat tegnologie 'n impak op die bestuurstaak gehad het, is ongetwyfeld waar. Dit help in die eerste plek vir bestuur om hulle taak 'beter' uit te voer, maar skep ook onvermydelik vrae. Drucker (1981: 12) het dan ook daarop gewys dat dit belangrik is dat daar geleer word om tegnologie te bestuur, nie net om dit aan te wend nie. Dit vereis 'n begrip van die proses van tegnologie en die dinamika daarvan.

Tegnologie het reeds so ontwikkel dat daar tussen gevorderde tegnologie en tegnologie onderskei word. Gevorderde tegnologie, wat 'n wetenskaplike en ingenieursgrondslag het, met 'n gepaardgaande hoè eenheidskoste en minder menslike betrokkenheid, het 'n omvangryke en drastiese impak op bestuur, die gemeenskap en ekonomie, asook op elke individu se lewe (Drucker, 1981 : 27).

Daar bestaan 'n groot besorgdheid dat moderne tegnologie so ver ontwikkel het in terme van effektiwiteit en meganisasie dat menslike en omgewingswaardesisteme bedreig word. Hierdie gevolge/effekte mag gevind word in afwesigheid, werkontevredenheid, vervreemding, besoedeling, afname in die waarde van werk, asook ander sosiale en ekonomiese afwykings.

Verandering in tegnologie het sosiale, ekonomiese en politieke invloede. Tegnologie speel egter ook 'n belangrike rol in produk tiwiteit, wat ook 'n nasionale sowel as organisasievraagstuk is.

Alhoewel tegnologiese ontwikkelings druk op die gemeenskap plaas, gebruik die gemeenskap die tegnologie om behoeftes en aspirasies te bevredig. Volgens Miner ( $1985: 603)$ sou die bestuur van tegnologie dus die versoening tussen hierdie druk en vereistes beteken.

\section{Slotopmerkings}

Die bestuur van tegnologie is nie tot voorgenoemde fasette beperk nie, maar sluit onder andere ook projekbestuur, stelsels en prioretisering, die invloed van tegnologie op funksionele bestuur, asook robotika in. Die navorsing het egter getoon dat die grootste gebrek en behoefte aan kennis binne die terreine soos bespreek, bestaan. Navorsing wat meer lig op hierdie onderwerpe kan werp sou dus noodwendig 'n groot bydrae ten opsigte van die uitbou van bestuurskennis en -vaardigheid, lewer.

\section{Bestuur van hoèvlakmannekrag}

\section{Oriëntering}

Vanuit ' $n$ bestuursoogpunt is verandering nie meer ' $n$ seldsaamheid nie, maar 'n werklikheid van die laat 20 ste

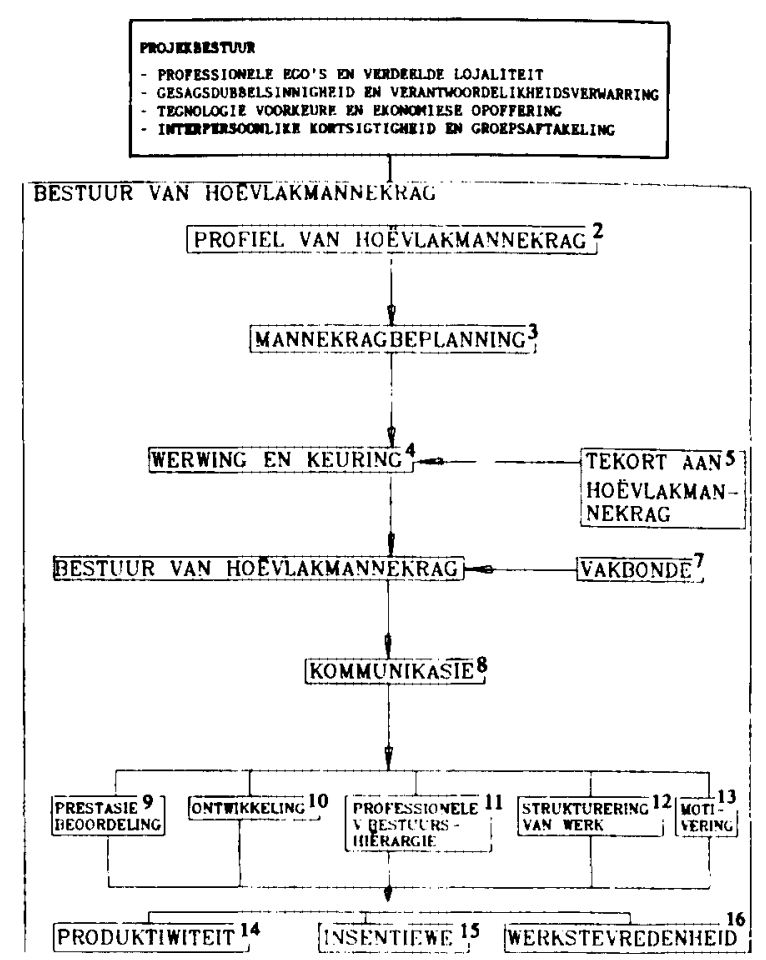

Figuur 8 Die bestuur van hožvlakmannekrag

eeu. Daar word ook voorspel dat die tempo van verandering nie gaan afneem nie, maar eerder sal toeneem en dat die taak van bestuur veeleisender en meer gekompliseerd gaan raak. Die verwagting is dat die bestuur van hoëvlakmannekrag besondere kwaliteite en vaardighede vereis en dat dit ten opsigte van bepaalde aspekte van die algemene bestuurstake verskil.

Enkele van hierdie aspekte wat moontlik besondere eise mag stel, is deur middel van onderhoude wat deur kruisverwysings in ' $n$ ontledingsmatrys ontleed is, aangevul deur' $n$ literatuurstudie, bepaal.

Die verband tussen die onderskeie aspekte wat of as 'anders' of in besonder van toepassing op hoèvlakmannekrag uitgekristaliseer het, word hoofsaaklik gekenmerk deur opeenvolgende interafhanklikheid. Ten einde 'n geheelbeeld te verkry, word hierdie elemente diagrammaties in Figuur 8 voorgestel. Daar word nie gepoog om die onderlinge verband tussen die elemente aan te dui nie, maar eerder om die talle selfstandige elemente wat binne hoèvlakmannekrag geintegreer is, weer te gee.

\section{Projekbestuur}

Daar bestaan 'n groeiende geneigdheid in sowel die openbare- as privaatsektor om organiese organisasiestrukture aan te wend in 'n poging om die snelle tegnologiese veranderings en unieke klientvereistes te hanteer. Volgens Greiner \& Schein $(1981: 17)$ is sodanige organisasies geneig om matriksstrukture aan te wend ten einde 'n verskeidenheid projekte, waarby spesialiste uit verskillende funksionele gebiede betrek is, te bestuur.

Nuwe bestuursoplossings/beginsels is nodig ten einde samehorigheid en rigtinggewing binne 'n projekgeorienteerde matriks te bevorder sonder dat die 
noodsaaklike buigsaamheid ondermyn word.

Weens die toenemende geneigdheid tot die benutting van hoevvlakmannekrag binne projekverband, word die elemente wat die bestuur van hoëvlakmannekrag karakteriseer in projekbestuur belangrik. Bo en behalwe die elemente soos vervat in Figuur 8, speel vier ander fasette volgens Greiner \& Schein (1981 : 17) 'n belangrike rol in die bestuur van hoëvlakmannekrag binne projekverband. Hulle som dit as professionele ego's en verdeelde lojaliteit, gesagsdubbelsinnigheid en verantwoordelikheidsverwarring, tegnologie voorkeure en ekonomiese opoffering en interpersoonlike kortsigtigheid en groepsaftakeling, op.

Enkele bestuursaspekte wat gedifferensieerd by die bestuur van hoëvlakmannekrag toegepas word

\section{Profiel van höevlakmannekrag}

Daar moet nog tot 'n groot mate bepaal word watter kategoriee werknemers onder die term hoëvlakmannekrag ressorteer. Voorlopig word dit aanvaar dat dit innoveerders, entrepreneurs, ingenieurs, wetenskaplikes, professionele persone en persone in middelbestuursvlak en hoèr poste insluit - slegs indien hulle spesialistake bo en behalwe hul bestuurstake moet uitvoer.

Gebaseer op definisies en ander historiese sowel as moderne opvattings, kan die volgende profiel van hoèvlakmannekrag voorlopig saamgestel word: dra van risiko; omskepping van produksiefaktore in produkte; beskikkingsmag oor produksie-elemente; neem van inisiatief; aanvaarding van onsekerheid; innoverend en kreatief/ skeppend; leidinggewend in die onderneming; glo in leierskap; persoonlikheid en intuïsie; persoonlike visie; werkolis; buigbaar; opgelei en gesofistikeerd; loopbaangeoriënteerd; werk outonoom: dikwels eksentriek; goeie selfbeeld; kan doelwitte deur spanwerk bereik; laag in konformiteit; onbuigsaamheid en konservatisme. (Saamgestel uit: Jooste, 1984: 33; Keller, 1980: 3-4; Nussbaum, Wilson, Moskowitz \& Beam, 1985: 6279; Kanter, 1985: 95-105).

\section{Tekort aan höevlakmannekrag}

In die literatuur is daar verskeie verwysings na die probleem van 'n tekort aan hoëvlakmannekrag.

'Tegnologiese ontdekking het "epidemiese" afmetings aangeneem en onder andere gelei tot die sogenaamde kompaktering van tyd. Wetenskaplike kennis verdubbel elke tien jaar, en die invloed op die individu is voor die handliggend - verouderde individue. Enkele voorbeelde is die rekenaar, televisie, nuwe wyses van telekommunikasie, ruimtetegnologie en die laserstraal.' (Du Preez, 1985: 1). Volgens Sutton (1980:5) nader SuidAfrika ' $n$ tydperk van ernstige tekort aan vaardige, professionele en bestuursmannekrag, veral aangesien hierdie mannekrag tradisioneel uit die blanke bevolking gekom het en hierdie tekorte nie vanuit interne bronne aangevul kon word nie.

Aanvullend hiertoe het die tak vir Ekonomiese Beplanning van die Kantoor van die Eerste Minister in 'n vooruitskatting van Suid-Afrika se mannekragbehoeftes bevind dat die persentasie professionele en verwante
Tabel 1 Mannekragtekorte

\begin{tabular}{lc}
\hline Beroepsgroep & Vakaturekoers (\%) \\
\hline Professioneel, semi-professioncel en tegnies & 7 \\
Ingenieurs (uitgesonderd bedryfsingenieurs) & 33 \\
Ingenieurstegnikus & 18 \\
Tegnikus-tekenaar & 9 \\
Opleidingsbeampte/werkstudiebeampte & 10 \\
\hline
\end{tabular}

Die res nie hier van toepassing nie

(Verslag van die Nasionale Mannekragkommiasie 1983:128)

werkers van $9 \%$ van die totale arbeidsmark in 1977 tot $11,3 \%$ in 1987 sal toeneem; en die persentasie arbeiders gedurende dieselfde tydperk van $22 \%$ tot $17,6 \%$ sal daal. (Mannekragkommissieverslag, 1981: 82)

Die bevindings in 'n opname deur die Departement van Mannekrag in 1983, wat 'n groot aantal beroepe dek en inligting verskaf omtrent tekorte van mannekrag op 'n gedetailleerde beroepsgrondslag, word in Tabel 1 weergegee.

Alhoewel die dringendheid en omvang van die tekort aan hoëvlakmannekrag wel deeglik besef word, lè die veld na die oplossing van die probleem nog braak.

\section{Bestuur(der) van höevlakmannekrag}

Die algemene hoevvlakwerknemer het bepaalde verwagtinge ten opsigte van sy bestuurder, onder andere dat hy 'n goeie begrip van sy ondergeskiktes se werk moet hè, waardering en aanmoediging moet verskaf en effektiewe beplanning en skedulering moet doen (verwerk uit Farris, 1973).

Faktore wat sodanige beoordeling moontlik sou beinvloed en wat waarskynlik 'n belangrike rol speel in die sukses van die dag-tot-dag-bestuur van hoevlakmannekrag word in Tabel 2 gegee.

\section{Tabel 2 Faktore wat beoordeling be invloed}

Die verband tussen die bestuurder se toesighovervaardighede en die groep se innovasieprestasie.

Tydsdruk waaronder daar gewerk word.

Die informele organisasiestruktuur.

Toesighouding as 'n proses van invloed.

Die bestuur van doelwitstelling.

Invloed op die interaksie wat binne informele organisasiestrukture voorkom.

Fasilitering van die professionele groei van sy ondergeskiktes.

\section{Prestasicbeoordeling}

Die onderskeie respondente het eenparig in hulle terugvoer aangedui dat prestasiebeoordeling van hoèvlakmannekrag, veral vanweè die hoè koste verbonde aan hierdie mannekrag, noodsaaklik is. Hulle is dit egter ook eens dat die algemene beoordelingstegnieke vir die laer vlakke van mannekrag nie toepaslik is nie, en dat daar 
na hul wete nie tans 'n beoordelingstegniek bestaan wat aan die besondere vereistes van die beoordeling van hoèvlakmannekrag voldoen nie.

Die ontwerp en ontwikkeling van 'n prestasiebeoordelings-/ metingstegniek sou dus aan 'n groot bestaande behoefte in die mark voldoen. Sodanige beoordelingstegnieke sou egter bepaalde aspekte, soos deur die respondente geidentifiseer, moet insluit, ten einde aan hulle vereistes te voldoen. In die eerste plek is daar die werkvermoë in 'n onsekere, dinamiese en komplekse omgewing waar hoë eise ten opsigte van 'n individu se tegniese kennis, selfstandige vernoë tot ontleding, navorsing en ontwerp, kreatiwiteit en diskresie gestel word. In die tweede plek is daar persoonlikheidseienskappe soos motivering, aanvaarding van gesag, interpersoonlike verhoudinge en behoefte aan erkenning betrokke. Bykomende velde van beoordeling sluit publikasies, uitnodigings na konferensies, makkerbeoordeling en interpersoonlike dimensies in.

Matriksstrukture is by uitstek arbeidsintensief. Hierdie arbeidsfaset van so 'n organisasie is ook buitengewoon duur weens die hooggekwalifiseerde professionele persone wat vir hul kennisbydrae aangewend word. Daar is 'n groot bykomende kostelas opgesluit in die klem wat daar op goedopgeleide professionele persone geplaas word. Hulle is geneig om sterk tot hulle professionele dissiplines georiënteerd te wees en beoordeel hulle loopbaanvordering en vergoedingspakket relatief tot hulle professionele gelykes in ander ondernemings. Lojaliteit aan 'n bepaalde onderneming is sekondêr tot die professionele norme, waardes en standaarde van sy eie dissipline.

Topbestuur van 'n onderneming (veral die met 'n projek/ matriksstruktuur) het 'n besondere probleem in die hantering van hierdie sensitiewe professionele werknemers. Hulle moet enersyds die beste professionele talente aantrek en mobiliseer ter bereiking van ondernemingsdoelwitte en produkte terwyl hulle andersyds 'n opwindende klimaat vir professionele ontwikkeling moet skep. Volgens Greiner \& Schein (1981: 18) sal tradisionele bestuurshenaderings, soos die bevordering van professionele persone na bestuursloopbane, uitvoering van direkte toesig, of die skryf van presiese posbeskrywings, heel waarskynlik in die bereiking van hierdie tweërlei doelwitte misluk. 'n Oplossing sou volgens hulle die daarstel van 'n professionele hiërargie parallel aan die bestuurshiërargie wees.

Dit sou beteken dat salarisskale hoogs kompeterend met die van die professionele markte moet wees. Bestuur sou ook moes aanvaar dat die uitstaande professionele persoon binne die onderneming meer as sy toesighouer kan verdien. Ander voordele sou ook vir professionele persone van belang wees, soos: interne seminare, reisvoordele om konferensies by te woon, afwesigheidstoelaes en ander verlofvoordele.

Ten slotte sal daar ook aandag aan die seleksie van sleutelfunksionele bestuurders vir elk van die professionele dissiplines gegee moet word. Hierdie persone

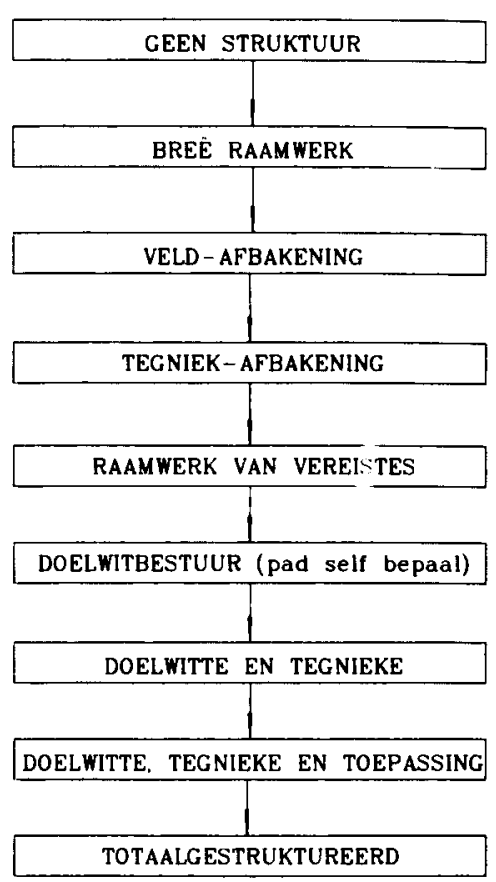

Figuur 9 Spektrum van struktureringsaltematiewe

sal hoogs gerespekteer moet wees vir hul tegniese vermoëns, terwyl hulle ook noue aansluiting by ondernemingsdoelwitte vind.

\section{Taakstrukturering}

Bestuur verskil grootliks ten opsigte van hul beoordeling van die hoeveelheid struktuur wat hoèvlakmannekrag aan hul taak verleen wil hê. Weens hierdie verskil in mening heers daar onsekerheid by bestuur oor die toepassing daarvan.

Navorsing oor hierdie onderwerp sou beteken dat die totale spektrum van alternatiewe ondersoek word en dat daar vasgestel word wat die presiese behoefte by hoèvlakmannekrag is. Dit sou nie alleenlik die bestuurstaak bevorder nie, maar ook die frustrasie wat onder sowel bestuur as die hoevvlakmannekrag bestaan, verminder.

Die spektrum van struktureringsaltematiewe wat tydens die voorstudie bevind is, sluit die alternatiewe soos in Figuur 9 vervat. in (dit mag moontlik deur verdere navorsing uitgebrei word).

\section{Motivering}

'n Kennis van motivering is belangrik vir bestuur aangesien hulle volgens definisie werk deur mense gedoen kry. Motivering is egter nie die enigste wyse waarop 'n werknemer se prestasievlak beinvloed kan word nie. Twee ander belangrike faktore is die individu se vermoèns en die individu se begrip van watter optrede vir die bereiking van hoë prestasie nodig is, naamlik rolpersepsie. Bowman (1977 : 64) stel dat erkenning, bevordering en persoonlike groei die kern van die motivering van hoëvlakmannekrag vorm. Figuur 10 bevat ook ander aspekte wat as motiveerders van hozvlakmannekrag ingesluit kan word. 


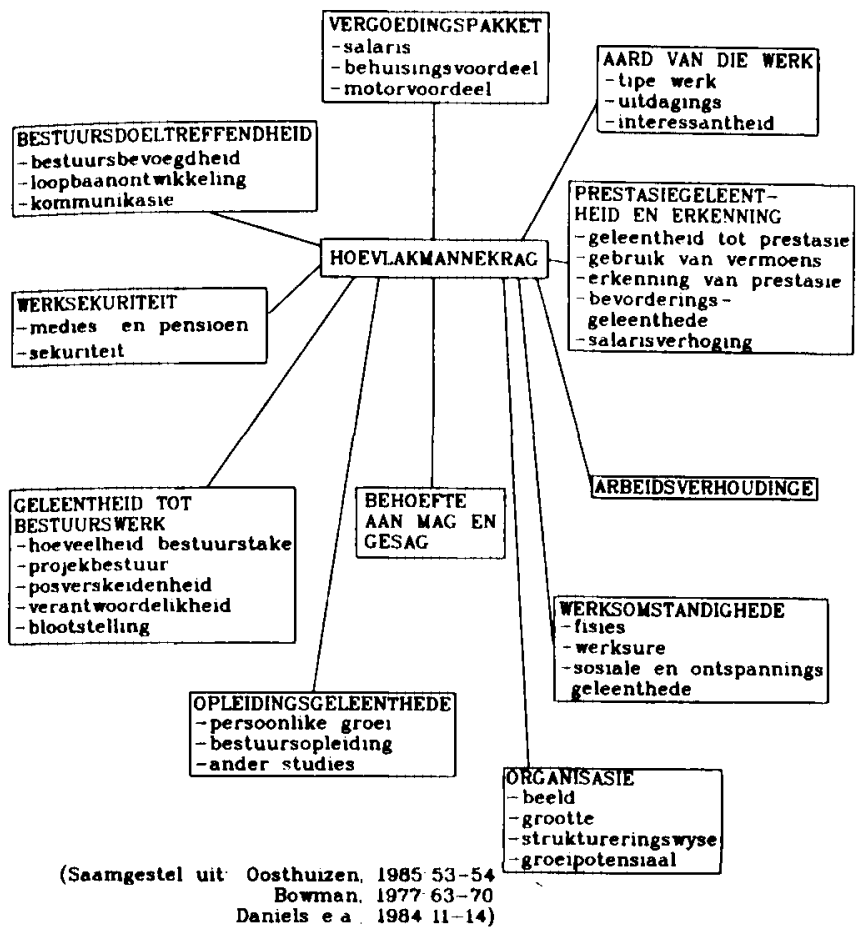

Figuur 10 Veld van moontlike motiveerders van hoẻvlakmannekrag

\section{Aanspoorders}

Sedert die dae van wetenskaplike bestuur en Frederick Taylor is die klem by die aanwending van aanspoorders by individuele- eerder as groepsbeloning. Die Westerse beskawing se waardesisteem, waar elke individu na sy eie belange omsien, skakel dus goed hierby in.

Weens die komplekse en wisselende aard van die take wat deur hoèvlakmannekrag uitgevoer word, is daar baie geleentheid tot wisselende prestasievlakke. Met die ontwerp van aanspoorders vir hierdie vlak van mannekrag moet daar by die onderneming se bepaalde verwagtinge begin word. Die mate waartoe daar dus aan hierdie verwagtinge voldoen word of waartoe die verwagtinge oorskry word, sou dan die aansporing bepaal.

Aanspoorders op hierdie vlak skep gevolglik twee belangrike probleme, naamlik: watter prestasiestandaard of verwagting daar gestel moet word, en wat vir so 'n individu as aansporing sou dien.

Die prestasiestandaard is baie nou aan 'n bepaalde onderneming verbonde, terwyl die aanspoorders meer ' $n$ breë algemene aanwendingswaarde het. Aangesien daar nog heelwat twyfel bestaan oor wat presies as aanspoorders sal dien, kan die volgende moontlikhede onder andere ondersoek word: kontantbonusse, aandeelhouding (aankoop van aandele teen huidige markwaarde), bykomende byvoordele en erkenning deur middel van statussimbole.

\section{Werktevredenheid}

Die aanvanklike besluit van ' $n$ individu om by ' $n$ bepaalde onderneming in diens te tree, is gebaseer op die mate waartoe die onderneming aan die vereistes voldoen wat die individu as voorwaandes gestel het. $\mathrm{Na}$ indienstrede is daar die geleentheid om hierdie besluit te evalueer.

'n Sosialiseringsproses vind plaas waar die organisasie bewustelik of onbewustelik poog om die verwysingsraamwerk van die individu sodanig aan te pas dat sy gedrag meer in coreenstemming met die organisasie se norme en standaarde is. Die individu kry weer deur kreatiewe individualisme die geleentheid om op konstruktiewe wyse die organisasie te beinvloed en vernuwe.

$\mathrm{Na}$ die wedersydse beinvloedingsproses tydens die aanvanklike indiensperiode vind daar gewoonlik 'n proses plaas waar die partye mekaar onderling aanvaar, en dit word deur terugvoering op verskeie wyses uitgedruk (Oosthuizen, 1985: 24-25).

Die definisie van Lawler (1973: 77) kan gevolglik ten opsigte van werktevredenheid aangewend word, naamlik dat tevredenheid bepaal word deur die verskil tussen die individu se verwagtinge en dit wat hy ontvang.

Die hoe koste verbonde aan die werwing, keuring, plasing en ontwikkeling van hoèvlakmannekrag bring mee dat omset onder hierdie kategorie werknemers tot die minimum beperk moet word. Dit kan alleenlik geskied indien daar werktevredenheid onder hierdie groep werknemers heers. Ten einde hierdie werktevredenheid te kan bewerkstellig moet 'n onderneming oor kennis (wat tans nog nie beskikbaar is nie) van hoevlakmannekrag se verwagtinge beskik.

\section{Slotopmerking}

Dat die bestuur van hoèvlakmannekrag kompleks is en talle ander fasette soos produktiwiteit, kommunikasie en indiensneming insluit, is ongetwyfeld waar. Navorsing op die geìdentifiseerde terreine mag egter bydra tot 'n verhoging in kennis en vaardigheid van bestuur wat weer hierdie hövlakproduksiebron positief mag beinvloed.

\section{Enkele terreine vir navorsing in Suld-Afrlka}

Tydens die studie het etlike terreine waarop navorsing in Suid-Afrika gedoen behoort te word, duidelik na vore gekom. Navorsing ten opsigte van 'n nasionale strategie vir tegnologie vir Suid-Afrika, die invloed van die intermedière strata op strategiese beplanning en die rol van strategiese beplanning in die bestuur van tegnologie het noodsaaklik geword.

Die suksesvolle integrering van vooruitskatting van tegnologie by die bestuur van tegnologie is ' $n$ verdere terrein vir navorsing, veral die toepassing en noodsaaklikheid van voorspellingstegnieke binne die verskillende tegnologie-omgewings; die betrokkenheid van bestuur by die aanwending van tegnieke; en die ontwikkeling van nuwe vooruitskattingstegnieke. Die verkryging van tegnologie vereis besondere aktiwiteite en bestuursvaardighede wat deur navorsing bepaal moet word. Die interafhanklikheid tussen die verkryging en die oordrag van tegnologie, die identifisering van die voorbereidingsaktiwiteite, ekonomiese-, sosiale- en bestuursteoriee betrokke by die oordrag van tegnologie, en die wyse waarop kennis by die ontvanger verseker kan 
word, is veral in Suid-Afrika belangrik. In die dualistiese Suid-Afrikaanse ekonomie is navorsing oor die weerstand teen tegnologie en die gevolge daarvan 'n voorvereiste vir langtermyn groei en oorlewing.

Enkele ander terreine sluit in navorsing oor fabrieksoutomatisering, die identifisering van faktore wat beperkend op tegnologieontwikkeling in Suid-Afrika inwerk, 'n nasionale strategie vir die ontwikkeling van inligtingstegnologie, die invloed van netwerke op intermedière vlak en die mate waartoe bestuur gekompliseer word deur die kompleksiteit en onstabiliteit van die inhoud van tegnologie.

Navorsing oor die bestuur van hoèvlakmannekrag dek 'n wye spektrum: bestuursoplossings vir professionele ego's en verdeelde lojaliteit; tegnologie voorkeure en ekonomiese opoffering; die profiel van hoëvlakmannekrag; en die tekort aan hoëvlakmannekrag. Navorsing oor die besondere bestuursvaardighede en -eienskappe wat nodig is, behoort gedoen te word. Die rol van prestasiebeoordeling, taakstrukturering, motivering, aanspoorders en professionele versus bestuurshiërargiee in die bestuur van hoèvlakmannekrag behoort nagevors te word. Nuwe visie ten opsigte van hierdie terreine is noodsaaklik.

Ten slotte behoort navorsing oor werkstevredenheid by hoëvlakmannekrag gedoen te word. Ten einde werkstevredenheid te kan bewerkstellig, moet die onderneming oor die volgende kennis beskik:

- watter verwagtinge het hoëvlakmannekrag aangaande die onderneming waarby hulle in diens tree?

- hoe belangrik is die bevrediging van elk van hierdie verwagtinge afsonderlik in die bereiking van werktevredenheid?

- watter rol speel elk van die volgende in die skep van werktevredenheid: aard van werk, prestasiegeleentheid en -erkenning, vergoedingspakket, bestuursdoeltreffendheid, werksekuriteit en bestuursverwante werk?

\section{Summary}

The ability to manage the routine, the recurring and the specifiable has been virtually perfected. However, the managerial function has become more complex during the latter part of this century. It is characterized by less recurring activities and a greater involvement in one-off activities due to technological innovations at almost an epidemical rate. Companies are confronted with constant change, risk and innovations. The mere fact that human beings, responsible for both management and production, develop and change at a slower rate than technology, creates new challenges for the managers of the 20th century. Extensive technological and intellectual sources are required both for the coping with and solving of the particular problems. In conjunction with the increasing need for these sources management of these resources requires particular attention. Whether the existing knowledge of management is sufficient and/ or applicable to manage these vast numbers of technological developments and related high-level manpower is a question that rises involuntarily.

Two main aspects arise from the above-stated questions, which seem to be very much the two sides of the same coin, namely:

a. management of technology.

b. management of high-level manpower.

Ascribed to the fact that technological innovations have an influence on organization structures, the de. velopment of organizations and industries, and the growth and survival of existing organizations and industries, management of technology proves to be a key to a competitive edge.

In addition a 'new' management theory and practice will have to be developed in areas where technical and intellectual sources play the dominant role. Management's primary involvement will be the recruitment of high-level manpower as well as the retaining, motivation, training and development thereof.

Theoretical and scientific research was undertaken to identify, analyse and systematize the various facets of management of technology and high-level manpower. Not only would it be possible to identify the various aspects of the subjects but also to determine the level of knowledge on the various aspects, available sources of information, and most important, areas for future research could be identified, outlined and described.

\section{Management of technology}

Management of technology can be divided into three dominant strata, namely: macro strata; intermediatory strata and micro strata.

Future research on management of technology should therefore be undertaken within the framework of these strata.

Macro strata: National strategy for the management of technology

During the preliminary investigation respondents emphasized that South Africa's major economic problem lies within the fact that it is both a first and third world economy. This economic problem is complicated by the shortage of high-level and trained manpower. In addition unemployment is caused by the present economic depression.

The question thus arises whether the time hasn't come for the development of a national strategy for technology for South Africa. It is therefore important that research is undertaken to determine the need for and to implement a national strategy for technology. It wouldn't only contribute to the recovery of the South African economy but would ensure constant growth and reduce unemployment.

\section{Intermediatory strata}

The intermediatory strata of management of technology is in its essence the intra-industrial management of technology. It therefore includes subsystems on intermediatory level such as intermediatory networks and databases.

Research on this level of the management of technology is important as it has implications for the generic strategies of companies. It could contribute to the improvement of efficiency and could improve the extent of 
production and distribution and thus influence leadership regarding costs. On a larger scale it could have an influence on the structure of industries regarding aspects such as mobility, competition and economic scales.

\section{Micro strata}

The micro strata can be divided into two main spheres the technology process and its various elements and the scope of aspects which influence this process.

The technology process consists of the following elements in chronological sequence: technology forecasting, strategy and information, procurement, technology transfer, project management, innovation, research and development, production and marketing.

The aspects that influence or are dependent on the technology process are the following: finance, manpower, limitations, functional structure of the organization, differentiation, robotics, information systems, systems and priorities.

Although the above-mentioned aspects have been identified as functions of management of technology, the detail remains unknown. It is therefore important that detail research be undertaken whereby information on aspects such as the following could be determined:

- the extent and importance of the various elements within and for management of technology;

- the composition of the various aspects within the framework of management of technology; and - the manner and extent to which management activities need to be adjusted to accommodate management of technology.

\section{Management of high-level manpower}

Apart from the fact that management's responsibilities are complicated by management of technology another (complicating) dimension is added by management of high-level manpower.

The expectation is that management of high-level manpower will require special qualities and skills and will differ from general management activities.

A number of aspects that might place special requirements were identified during the preliminary survey and include the following: project management, profile of high level manpower, recruitment, shortage of high level manpower, trade unions, professional hierarchy, communication, development, work structuring, motivation, productivity, incentives and work satisfaction.

It is therefore important to determine via research: - the manner and extent to which management activities need to be adjusted to accommodate management of high level manpower; and

- the character and disposition of the various aspects of management of high-level manpower.

\section{Aantekening}

1. Imoveenders, entrepreneurs, ingenieurs, wetenskaplikes, professionele persone en persone in middel-bestuursvlak en hoitr poste (stegs indien hulle spesialistake bo en behalwe hul bestuurstake uitvoer).

\section{Verwysings}

Arbose, J. 1985. Manufacturing: Management's new competitive weapon. Intern. Manage., 12-16, March.

Bowman, J.S. 1977. The meaning of work and the middle manager. California Manage. Rev., 19 (3): 63-70, Spring.

Cash, J.I. \& Konsynski, B.R. 1985. IS redraws competitive boundaries. Harv. Bus. Rev., 134-149, March-April.

Daniels, R.M., Patterson, J.W. \& Zimmerer, T.W. 1984. Understanding power, decision making, and the middle manager. Mid-South Bus. J., 4 (1) 11-14, January.

De Jesus, A.S.M. 1983. Transfer of incustry-orientated nuclear technology at Nucor. Pretoria: Nuclear development corp. of S.A. (Pty.) Ltd. 197 p.

Dizard, W.P. 1982. The coming information age. New York: Longman. 213 p.

Drucker, P.F. 1981. Towards the next economics. New York: Harper \& Row. 100 p.

Drucker, P.F. 1985. The changing world of the erecutive. New York: Times Books. 271 p.

Du Preez, N.P. 1985. Fasette van geintegreerde bestuur. Wesvalia:Potchefstroom. $104 \mathrm{p}$.

Farris, O.F. 1973. The technical supervisor: beyond the Peter Principle. Technology Rev., 75 (5), April.

Feder, B.J. 1981. Training managers to manage technology. New York Times, NYT 6/21/81: 1OE, June, Sunday 21.

Greiner, L.E. \& Schein, V.E. 1981. The paradox of managing a project-oriented matrix: establishing coherence within chaos. Slaan Manage. Rev., 17-22, Winter.

Howell, J.M. 1985. The economic renaissance of New England. Econ. Impact, 51 (e): 16-23.

Jooste, C.J. 1984. Is jy 'n ware entrepreneur? Die Ekonoom, 33,Mei.

Kanter, R.M. 1982. The middel manager as innovator. Harv. Bus. Rev., 60 (4): 95-105, July/August.

Kates, J. 1975. Technology transfer government laboratories to manufacturing incustry. Science council of Canada. Oshawa: Maracle Press. 61 p.

Kaufman, F. 1966. Data systems that cross company boundaries. Harv. Bus. Rev. 141, Jan/Feb.

Keller, R.T. 1980. A technical innovator: a literature review. Paper represented at the 10th annual national meeting of the Academy of Management Detroit: 1-14, August.

Lawler, E.E. 1973. Motivation in work organizations. Monterey: Brooks/Cole Publishing Co.

Maidique, M.A. \& Patch, P. 1978. Corporate strategy and technological policy. In: Readings in the management of innovation. 1982. Tushman, M.L. \& Moore, W.L. (ed.). London: Pitman Books. 273-285.

Miner, J.B. 1985. The practice of management. Ohio: Columbus: Charles E. Merrill Publishing Co. 714 p.

Nussbaum, B., Wilson, J.W., Moskowitz, D.B. \& Beam, A. 1985. The new corporate elite. Bus. Week, 2877: 62-79, January.

Oosthuizen, G.F. 1985. Organisasiekeuse en -evaluering in die ingenieursberoep. Direktoraat: Personeel - Krygkor. $67 \mathrm{p}$.

Quinn, J.B. 1967. Technological forecasting. Harv. Bus. Rev., 89-106, March/April. 
Stonier, T. 1983. The wealth of information. Butler \& Tanner: $214 \mathrm{p}$.

Suid-Afrika (Republiek). Statisties dekonomiese oorsig in verband met die begrotingsrede 19861987. Staatsdrukker, Pretoria. 42 p.

Suid-Afrika (Republiek). 1981. Verslag van die nasionale mannekragkommissie vir die tydperk 1 Januarie 1980 - 31 Desember 1980 . Uitgegee op gesag.

Sutton, R.V. 1980. Manpower planning and total economic strategy. People \& profits, 5, June.

United Nations. 1973. Guidelines for the acquisition of foreign technology in developing countries.
New York. 55 p.

Utterback, J.M. 1971. The process of innovation: A study of the origination and development of ideas for new scientific instruments. IEEE transactions on engineering management, 124-131, November.

Utterback, J.M. 1974. Innovation in industry and the diffusion of technology. Science, 183: 658-662, February.

Van Wyk, R. 1985. Technoscan. Stellenbosch: TechnoManagement (Pty) Ltd. 42 p.

Wheelwright, S.D. \& Hayes, R.H. 1985. Competing through manufacturing. Harv. Bus. Rev., 99-109, January/ February. 